\title{
Semi-dry mesophilic anaerobic digestion of water sorted organic fraction of municipal solid waste (WS-OFMSW)
}

\author{
Li Dong a,b,*, Yuan Zhenhong ${ }^{\mathrm{a}}$, Sun Yongming ${ }^{\mathrm{a}}$ \\ ${ }^{a}$ Guangzhou Institute of Energy Conversion, Chinese Academy of Sciences, Guangzhou 510640, China \\ ${ }^{\mathrm{b}}$ Key Laboratory of Renewable Energy and Gas Hydrate, Chinese Academy of Sciences, Guangzhou 510640, China
}

\section{A R T I C L E I N F O}

\section{Article history:}

Received 24 August 2009

Received in revised form 2 December 2009

Accepted 8 December 2009

Available online 29 December 2009

\section{Keywords:}

Municipal solid waste

Water separation technology

Anaerobic digestion

Mesophilic

Biodegradability

\begin{abstract}
A B S T R A C T
An innovative municipal solid waste separation technology - water separation was developed in China recently. The purpose of this study was to evaluate the feasibility of anaerobic digestion from water sorted organic fraction of municipal solid waste (WS-OFMSW) to methane. A group of bench-scale (35 L) mesophilic $\left(30 \pm 2{ }^{\circ} \mathrm{C}\right)$ batch anaerobic digestions were carried out with three total solids in reactor (TSr $=16.0 \%, 13.5 \%$ and $11.0 \%$ ). The biodegradability of WS-OFMSW with VS/TS of $61.6 \%$ was better than that of mechanically sorted OFMSW but still poor than that of source sorted OFMSW. No inhibitions of metal ions, volatile fatty acids and ammonia on anaerobic digestion were found. The reactors with $\mathrm{TSr}$ $16.0 \%, 13.5 \%$ and $11.0 \%$ achieved methane yield of 273,283 and $314 \mathrm{~L} / \mathrm{kgVS}$ and VS removal rate of $26.1 \%, 35.8 \%$ and $41.8 \%$, respectively. The average methane content in biogas was about $66 \%$ for all reactors.
\end{abstract}

(c) 2009 Elsevier Ltd. All rights reserved.

\section{Introduction}

Municipal solid waste (MSW) generation is rapidly increasing in China especially in big cities and the production of MSW in 2007 was 150 million tons (National Bureau of Statistics, 2007). Waste management has become one of the largest environmental concerns in the recent past. The scarcity of land and uncontrolled contamination with gas and leachate emissions made landfilling (Adhikari et al., 2006), which was formerly the main waste disposal method, no longer an option in China. Anaerobic digestion (AD) treatment of organic fraction of municipal solid waste (OFMSW) has been considered the main commercially viable option for both waste treatment and energy/nutrition generation, if the residue of $\mathrm{AD}$ is used as fertilizer.

A lot of studies on anaerobic digestion of OFMSW have been done at laboratory, bench and pilot scale by many scientists over the past fifteen years. The organic wastes used in previous studies included: market waste (Nguyen et al., 2007), fruit and vegetable waste (Bouallagui et al., 2005), household waste (Krzystek et al., 2001), kitchen waste (Rao and Singh, 2004), biowaste (Gallert et al., 2003) mechanically sorted organic fraction of mu-

\footnotetext{
* Corresponding author. Address: Guangzhou Institute of Energy Conversion, Chinese Academy of Sciences, No. 1, Nengyuan Rd., Wushan, Tianhe District, Guanzhou 510640, PR China. Tel.: +86 20 87051423; fax: +86 2087057737.

E-mail address: lidong@ms.giec.ac.cn (L. Dong).
}

nicipal solid waste (MS-OFMSW) (Charles et al., 2009), source sorted organic fraction of municipal solid waste (SS-OFMSW) (Davidsson et al., 2007) and unsorted municipal solid waste (Silvey et al., 2000). Factors influencing stability and efficiency of anaerobic digestion have been investigated. Factors such as temperature (Kim et al., 2002), substrate concentration (Forster-Carneiro et al., 2008), inoculum source (Forster-Carneiro et al., 2007), inocula proportion (Lopes et al., 2004), retention time (Edgar-Fernando et al., 2006), organic loading rate (Gómez et al., 2006), mixing (Stroot et al., 2001) and co-digestion (Hartmann and Ahring, 2005).

Thanks to the introduction of source separate collection and many mechanical separation plants, the AD treatment of OFMSW was boosted considerably in the past fifteen years in Europe. A wide range of process systems of full or commercial scale were applied to treat SS-OFMSW, MS-OFMSW and mixture of them and municipal sewage sludge (Bolzonella et al., 2006a,b). The wet fermentation systems included BTA, VAGRON, AVECON, etc., and the dry systems involved Valorga, Dranco, Kompogas and Biocel process (Reith et al., 2003).

Reviewing back China, since there was no imperative efficiently introduction of source separate collection and the existing waste separation technology was not mature, so far, there is no full scale application of AD for treating of OFMSW. The researches mainly stay at the lab and pilot scale with the simple organic waste, such as simulated OFMSW (Li et al., 2008), kitchen waste (Li et al., 2009) and manually sorted household waste (Wu and Sun, 2006). Re- 


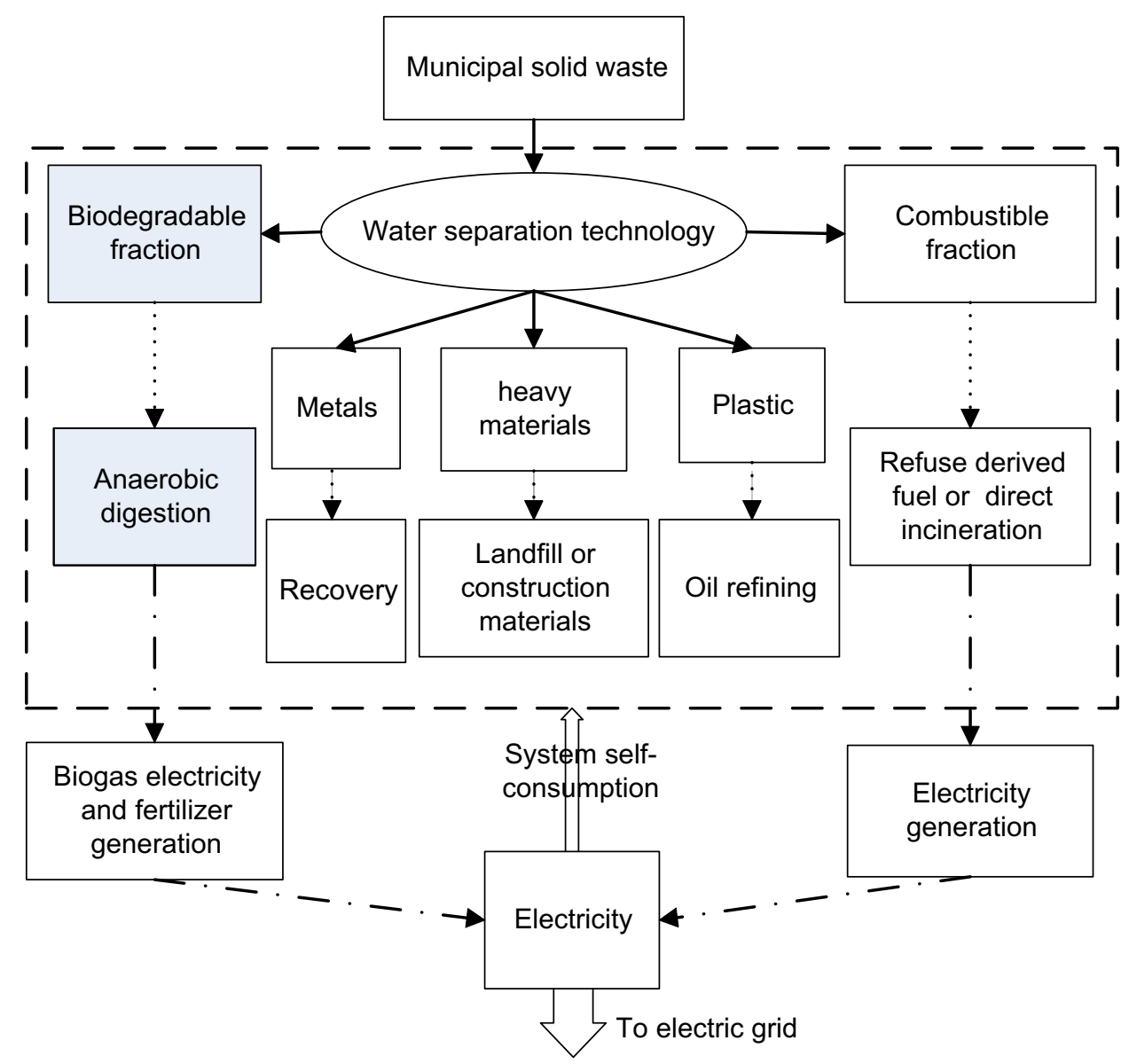

Fig. 1. A proposed MSW treatment based on water separation technology.

cently, an innovative waste separation technology developed by WST International (Holding) Limited Company was phased into demonstration (WST, 2009). This separate system relies on the buoyant and sink force of water and with the assistance of a series of machine, thus, it is named as water separation technology (WST). The "completely mixed" municipal solid waste is separated into five classes, including biodegradable fraction, metals, heavy materials, plastics and combustible fraction (Fig. 1). The biodegradable fraction which is referred to as water sorted organic fraction of municipal solid waste (WS-OFMSW) is a mixture of kitchen waste, fruit and vegetable waste, garden waste, waste paper, etc. As a partner, our task is to determine the composition of WS-OFMSW and to evaluate the feasibility of anaerobic digestion for methane production from WS-OFMSW.

\section{Methods}

\subsection{Anaerobic reactor}

The assays were conducted on batch bench-scale reactor with total volume of $35 \mathrm{~L}$ (Fig. 2). The cover of each reactor incorporated with five separate ports for different functions: $\mathrm{pH}$ online monitoring, mechanical agitation system, releasing of biogas for measurement of the biogas generation and composition, temperature control by means of recirculation of the internal hot water, liquid sampling. Anaerobic digestions were carried out at $(30 \pm 2)^{\circ} \mathrm{C}$ and the mixing run 5 times per day with stirring speed $20 \mathrm{rpm}$ and time $10 \mathrm{~min}$.

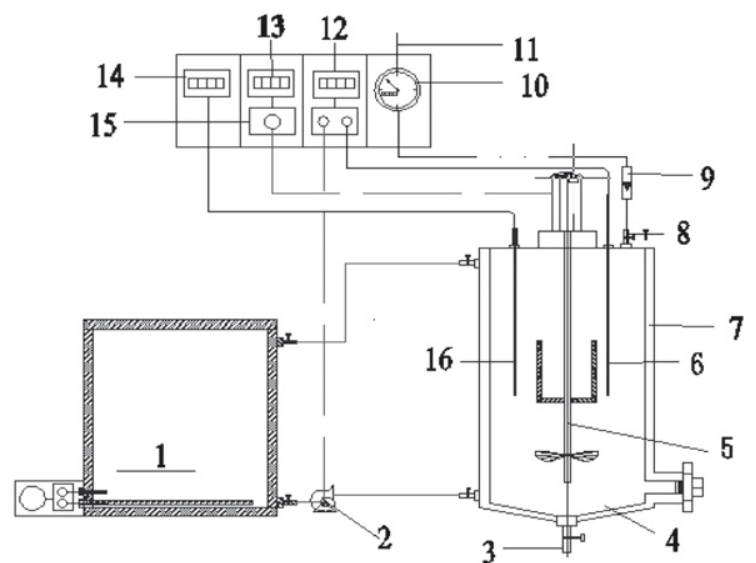

1.Hot water tank 2.Circulating pump 3.Liquid sampling port 4.Digester 5.Mixer 6.Thermocouple probe7.Hot water interlayer 8.Gas sampling port 9.Rotermeter 10.Wet gas meter 11.Biogas outlet 12.Temperature controller 13.Timer 14.pH meter 15.rpm governor 16.pH probe

Fig. 2. Experimental apparatus of $35 \mathrm{~L}$ anaerobic digestion.

\subsection{Substrate and inoculum preparation}

Twenty tons original municipal solid waste was collected from Guangdong Boluo area and transported to WST waste treatment plant. The characteristics of the original MSW is shown in Table 1 . The biodegradable fraction sorted by water separation technol- 
Table 1

Characteristics of the MSW collected in Guangdong Boluo area.

\begin{tabular}{lll}
\hline Fractions & Wet basis $(\%, w / w)$ & Dry basis $(\%, w / w)$ \\
\hline Food waste & 48.65 & 32.95 \\
Paper and cardboard & 6.01 & 6.41 \\
Wood and bamboo & 8.41 & 7.00 \\
Textile & 4.80 & 4.95 \\
Plastic & 11.72 & 14.55 \\
Metals & 0.30 & 0.59 \\
Glass & 8.41 & 16.44 \\
Other inorganic & 11.70 & 17.11 \\
Total & 100.00 & 100.00 \\
\hline
\end{tabular}

ogy (WST) was stored in a mixing tank. About $100 \mathrm{~kg}$ homogenous wet WS-OFMSW was taken to the laboratory. Part of it was used for material analysis and the remaining was used as substrate of anaerobic digestion. The digested sludge from manure treatment plant was initially filled into the acclimation reactor, then, a little WS-OFMSW was repeatedly fed into the acclimation reactor for one month. Finally, the digested residue from acclimation reactor was used as inoculum in this experiment. The TS, VS, pH, volatile fatty acids (VFAs) and ammonia nitrogen $\left(\mathrm{NH}_{4}^{+}-\mathrm{N}\right)$ of inoculum were $11.26 \%, 4.77 \%, 6.89$, $5741 \mathrm{mg} / \mathrm{L}$ and $113 \mathrm{mg} / \mathrm{L}$.

The raw feedstock (WS-OFMSW) of $21.5,18.1$ and $15.2 \mathrm{~kg}$ were loaded into three reactors, respectively. Then all reactors were inoculated with inoculum $(20 \% \mathrm{w} / \mathrm{w})$. Water was added to obtain the desired total solid percentage in reactor $(\mathrm{TSr}=11.0 \%, 13.5 \%$, $16.0 \%)$. The useful volumes for all reactors were about $75 \%$ in order to avoid pipe plug which may be resulted from expansion of digesting material.

\subsection{Analytical methods}

Total solid (TS) and volatile solid (VS were determined using standard techniques (APHA, 1995). Elementary analysis was determined with Vario EL element analyzer made in Germany. The component compositions (carbohydrates, crude fibers, lipids, proteins, total kjeldahl nitrogen) were determined based on Chinese Standard (GB/T 5009-2003). Heat values were measured by WGR-1 heat analyzer. The ammonia nitrogen was determined by FC-100 ammonia analyzer. The $\mathrm{pH}$ was determined by $\mathrm{pHS}-3 \mathrm{C} \mathrm{pH}$ meter. All tests were carried out three times and the data in this paper are mean values.

Biogas production was measured by the LML- 1 wet gas meter. The percentages of $\mathrm{H}_{2}, \mathrm{CH}_{4}$ and $\mathrm{CO}_{2}$ in headspace of reactors were determined using a gas chromatograph (Agilent 6890) equipped with a thermal conductivity detector (TCD) and a $2 \mathrm{~m}$ stainless column packed with Porapak Q (50/80 mesh). The operational temperature at the injection port, the column oven and the detector were $100{ }^{\circ} \mathrm{C}, 70^{\circ} \mathrm{C}$ and $150^{\circ} \mathrm{C}$, respectively. Argon was used as carrier gas at a flow rate of $30 \mathrm{~mL} / \mathrm{min}$.

Liquid sample was centrifuged with $6000 \mathrm{r} / \mathrm{min}$ at $0-4{ }^{\circ} \mathrm{C}$ and filtrated with $0.45 \mu \mathrm{m}$ cellulose acetate membranes. The concentration of volatile fatty acids (including acetate, propionate, butyrate, iso-butyrate, valerate and iso-valerate) were determined using a gas chromatograph (Agilent 6820) equipped with a flame ionization detector (FID) and a $30 \mathrm{~m} \times 0.25 \mathrm{~mm} \times 0.25 \mu \mathrm{m}$ fusedsilica capillary column (DB-FFAP). Nitrogen was used as carrier gas at a flow rate of $30 \mathrm{~mL} / \mathrm{min}$ and split ratio was 1:50. The operational temperature at the injection port and detector were $250{ }^{\circ} \mathrm{C}$ and $300{ }^{\circ} \mathrm{C}$. The initial temperature of oven was $100^{\circ} \mathrm{C}$ for $5 \mathrm{~min}$, then increased to $250^{\circ} \mathrm{C}$ at rate of $10^{\circ} \mathrm{C} / \mathrm{min}$ and maintained for $12 \mathrm{~min}$.
Table 2

Characteristics of WS-OFMSW.

\begin{tabular}{|c|c|c|c|}
\hline Parameters & WS-OFMSW & SS-OFMSW ${ }^{\mathrm{a}}$ & MS-OFMSW \\
\hline Particle size (mm) & $\leqslant 10$ & - & $\leqslant 30$ \\
\hline Density $(\mathrm{g} / \mathrm{L})$ & 933 & - & 295 \\
\hline $\mathrm{TS}(\mathrm{g} / \mathrm{kg})$ & 184 & $170-370$ & 172 \\
\hline Heat value (MJ/kgTS) & 21.0 & $19-22$ & - \\
\hline VS (\% of TS) & 61.6 & $81-92$ & 43.0 \\
\hline Ash (\% of TS) & 38.4 & $8-19$ & 57.0 \\
\hline Carbohydrates (\% of TS) & 37.8 & - & - \\
\hline Crude fibers (\% of TS) & 8.4 & $8-26$ & - \\
\hline Proteins (\% of TS) & 14.2 & $10-18$ & - \\
\hline TKN (\% of TS) & 2.3 & - & 2.6 \\
\hline Lipids (\% of TS) & 9.6 & $10-18$ & - \\
\hline Carbon (\% of TS) & 37.7 & $45-52$ & - \\
\hline Hydrogen (\% of TS) & 5.7 & $6.4-7.8$ & - \\
\hline Oxygen (\% of TS) & 14.9 & - & - \\
\hline Nitrogen (\% of TS) & 3.3 & $2.2-3.1$ & - \\
\hline Sulfur (\% of TS) & 0.1 & 0.2 & - \\
\hline Phosphorus (\% of TS) & 0.2 & $0.3-0.6$ & - \\
\hline $\mathrm{C}: \mathrm{N}$ ratio & 11.4 & $15.5-20.5$ & 11.9 \\
\hline $\mathrm{pH}$ & 5.3 & - & 7.9 \\
\hline VFAs/mg L ${ }^{-1}$ & 431 & - & 2000 \\
\hline $\mathrm{NH}_{4}^{+}-\mathrm{N} / \mathrm{mg} \mathrm{L}^{-1}$ & 114 & - & 300 \\
\hline TMP (L/kgVS) & 713 & $583-734$ & - \\
\hline TMP (L/kgVS $)^{\mathrm{d}}$ & 508 & $495-548$ & - \\
\hline
\end{tabular}

a Source sorted organic household waste from five Danish cities (Davidsson et al. 2007).

${ }^{b}$ Mechanically selected organic fraction of MSW from the municipal treatment plant "Calandrias" located in Jerez de la Frontera, Spain (Forster-Carneiro et al. 2008).

Theoretical methane potential based on element composition $(\mathrm{C}, \mathrm{H}, \mathrm{O}, \mathrm{N})$

d Theoretical methane potential based on component composition (carbohydrates, proteins and lipids)

\section{Results and discussion}

\subsection{Substrate characterization}

Table 2 presents the characteristics of the WS-OFMSW. The WSOFMSW was shredded to $10 \mathrm{~mm}$ on field and the density is similar to that of water. The waste can be considered middle-solid substrate (TS $18.4 \%$ ). Nearly sixty-two percent of total solid is organic matter and the residue is soil, sand and other small inorganic particles. The biodegradability of WS-OFMSW is higher than that of MS-OFMSW, but still lower than that of SS-OFMSW. The majority of organic matter is carbohydrates followed by proteins and lipids. The ratio of $\mathrm{C}: \mathrm{N}$ is similar to results of MS-OFMSW.

Table 3

Metal contents of WS-OFMSW.

\begin{tabular}{llll}
\hline Metals & $\begin{array}{l}\text { Content in material } \\
(\mathrm{mg} / \mathrm{kgTS})\end{array}$ & $\begin{array}{l}\text { Content in reactor } \\
(\mathrm{mg} / \mathrm{L})^{\mathrm{a}}\end{array}$ & $\begin{array}{l}\text { Inhibitory level } \\
(\mathrm{mg} / \mathrm{L})^{\mathrm{b}}\end{array}$ \\
\hline $\mathrm{Na}$ & 1061.5 & 169.8 & $3500-5500$ \\
$\mathrm{~K}$ & 3656.8 & 585.1 & $2500-4500$ \\
$\mathrm{Ca}$ & 2106.1 & 337.0 & $2500-4500$ \\
$\mathrm{Mg}$ & 2301.2 & 368.2 & $100-1500$ \\
$\mathrm{Al}$ & 12108.8 & 1937.4 & 1000 \\
$\mathrm{Fe}$ & 13987.0 & 2237.9 & 1750 \\
$\mathrm{Zn}$ & 660.0 & 105.6 & 160 \\
$\mathrm{Cu}$ & 94.1 & 15.1 & 170 \\
$\mathrm{Cd}$ & 2.0 & 0.3 & 180 \\
$\mathrm{Cr}$ & 72.5 & 11.6 & 450 \\
$\mathrm{~Pb}$ & 80.7 & 12.9 & - \\
$\mathrm{Ni}$ & 29.6 & 4.7 & 250 \\
$\mathrm{Mn}$ & 79.6 & 12.7 & - \\
$\mathrm{Hg}$ & 1.2 & 0.2 & - \\
$\mathrm{As}$ & 10.1 & 1.6 & - \\
\hline
\end{tabular}

Based on the anaerobic digestion at $\mathrm{TSr} 16.0 \%$.

b Middle inhibitory level of metal ion on anaerobic digestion (Xu et al., 2006; Chen et al., 2008). 
The theoretical methane potential (TMP) was used to assess the maximal methane production from complete degradation of the organic matter. The theoretical methane potential can be both calculated from the element composition (content of $\mathrm{C}, \mathrm{H}, \mathrm{O}, \mathrm{N}$ ) and from the component composition (content of carbohydrate, protein, lipid) by the Buswell formula (Buswell and Neave, 1930). The results of WS-OFMSW are similar to that of SS-OFMSW. The element composition includes the non-biodegradable volatile solid (such as lignin and plastic), while this two parts are not included in the component composition. Therefore, only the theoretical methane potential based on the component composition can effectively reflect the biodegradability of organic waste.

Table 3 lists the metal contents of WS-OFMSW. The rank of metal content is $\mathrm{Fe}>\mathrm{Al}>\mathrm{K}>\mathrm{Mg}>\mathrm{Ca}>\mathrm{Na}>\mathrm{Zn}>\mathrm{Cu}>\mathrm{Pb}>\mathrm{Mn}>\mathrm{Cr}>-$
$\mathrm{Ni}>\mathrm{As}>\mathrm{Cd}>\mathrm{Hg}$. When the anaerobic digestion is operated at $\mathrm{TSr}$ of $16 \%$, the contents of $\mathrm{Al}$ and Fe look like beyond the inhibitory level on anaerobic fermentation. However, only the metal ions are responsible for the inhibition. The inhibition of metals on anaerobic digestion will be investigated in following batch anaerobic digestion tests.

\subsection{Evolution of $\mathrm{pH}, \mathrm{VFAs}$ and $\mathrm{NH}_{4}^{+}-\mathrm{N}$}

Fig. 3 illustrates the evolution of $\mathrm{pH}$, VFAs and ammonia nitrogen for three TSr. The initial pH was $5.4,5.6$ and 5.7 for TSr $16.0 \%$, $13.5 \%$ and $11.0 \%$. A $300 \mathrm{~mL}$ hydroxide sodium solution $(3 \mathrm{~N}$ ) which was the only addition in this experiment was added into all reactors at the end of first day and the $\mathrm{pH}$ increased to 6.8,
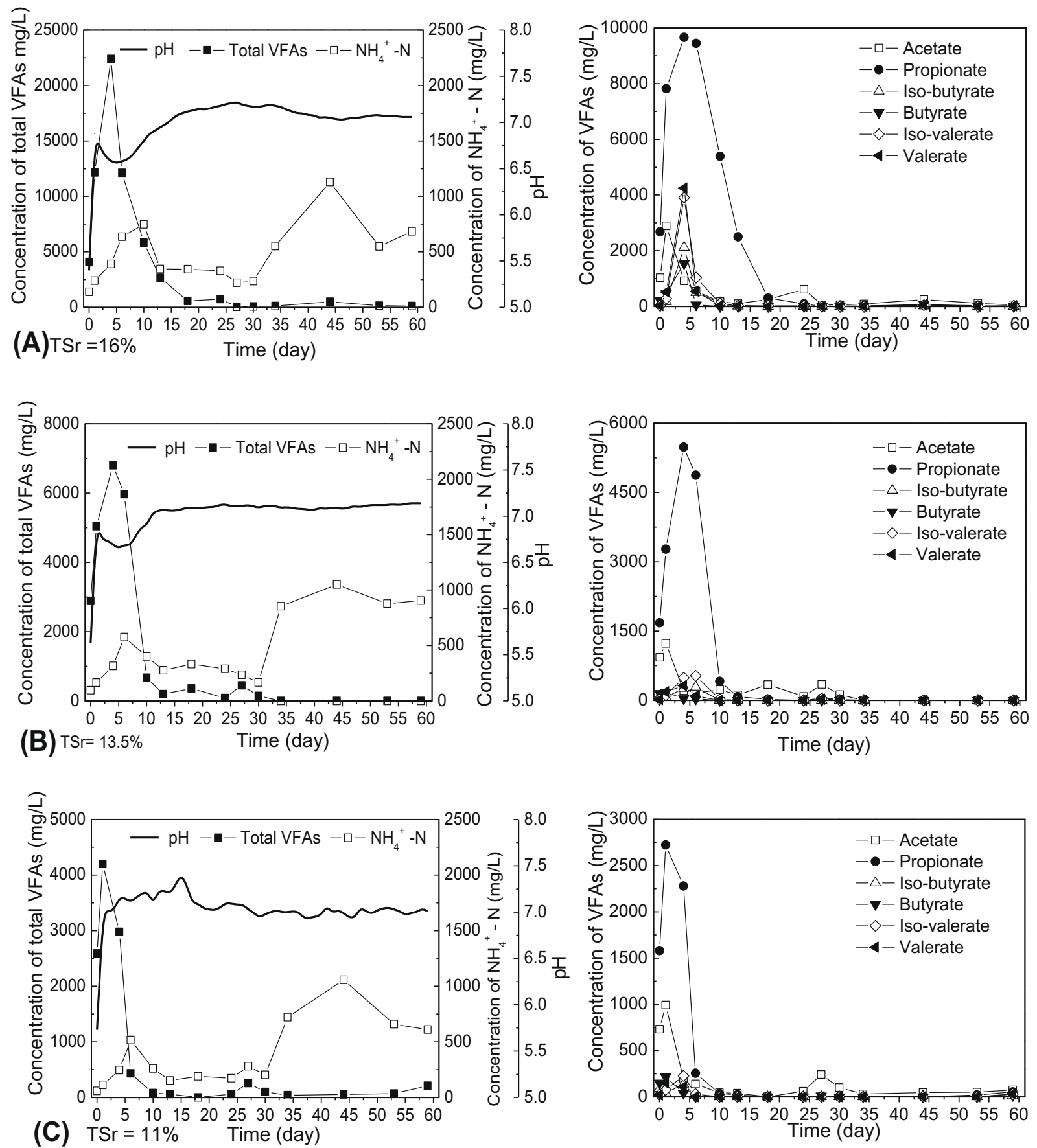

Fig. 3. Evaluation of total VFAs, $\mathrm{NH}_{4}^{+}-\mathrm{N}, \mathrm{pH}$ and VFAs for three TSr. 
6.9 and 7.0 , respectively. For the TSr $16.0 \%$ and $13.5 \%$, due to the accumulation of VFAs, the pH decreased to the lowest of 6.56 and 6.65 at the day 5 . And then, the $\mathrm{pH}$ increased to 7.0 at day 15 and day 11, respectively. Finally, the $\mathrm{pH}$ waved around 7.1. In case of TSr $11.0 \%$, the $\mathrm{pH}$ increased from 7.0 to 7.4 during the period of day 2 to 15 , and then, decreased until stabilizing at 7.0.

The profiles of the temporal evolution of total VFAs showed three stages: initially, an increase was observed from the day 0 to day 4,4 and 1 for TSr $16.0 \%, 13.5 \%$ and $11.0 \%$ with the maximum value of $22399 \mathrm{mg} / \mathrm{L}, 6800 \mathrm{mg} / \mathrm{L}$ and $4198 \mathrm{mg} / \mathrm{L}$. Later, total VFAs decreased until the day 18,13 and 10 , respectively. Finally, total
VFAs stabilized at $0-400 \mathrm{mg} / \mathrm{L}$ for all reactors. The concentration of volatile fatty acids in the reactor was determined by their generation rate and their consumption rate. During the first stage, hydrolysis and acidogenesis took place and the easy biodegradable fraction of organic waste was converted to volatile fatty acids (such as propionate and acetate). However, the methanogens were in adaptation period. During the second stage, aceticlastic methanogens were in exponential growth phase and the acetic acid consumption rate was higher than its generation rate even though the hydrolysis and acidogenesis were still going on. Hanaki et al. (1994) pointed out that the oxidation of propionate to acetate is

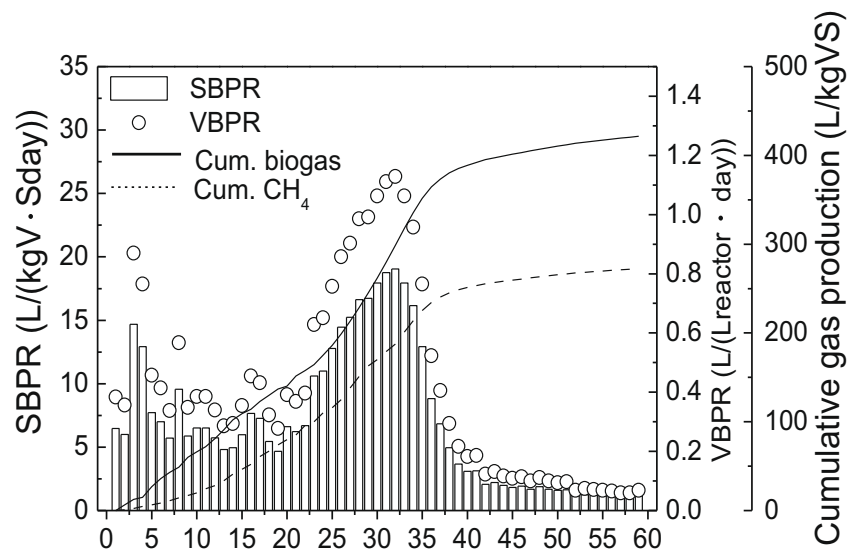

(A) $\mathrm{TSr}=16 \%$

Time (day)

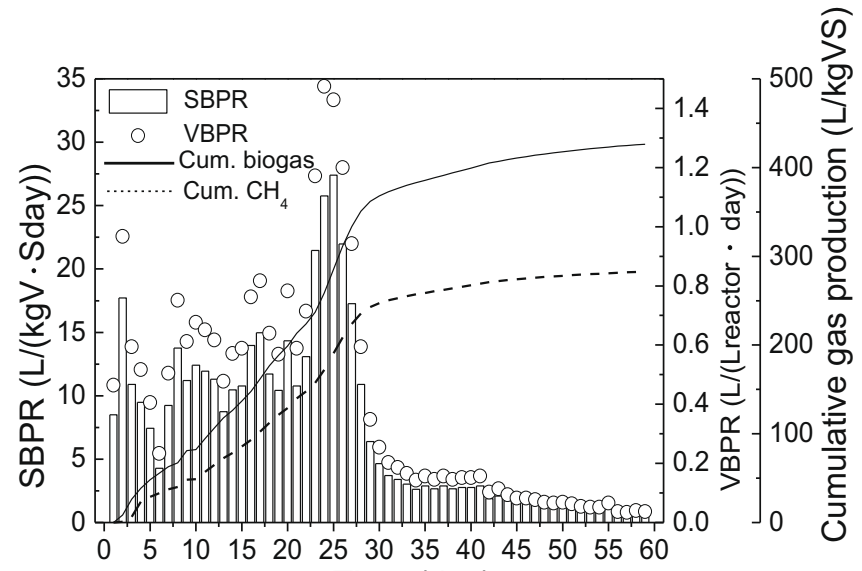

(B) $\mathrm{TSr}=13.5 \% \quad$ Time (day)

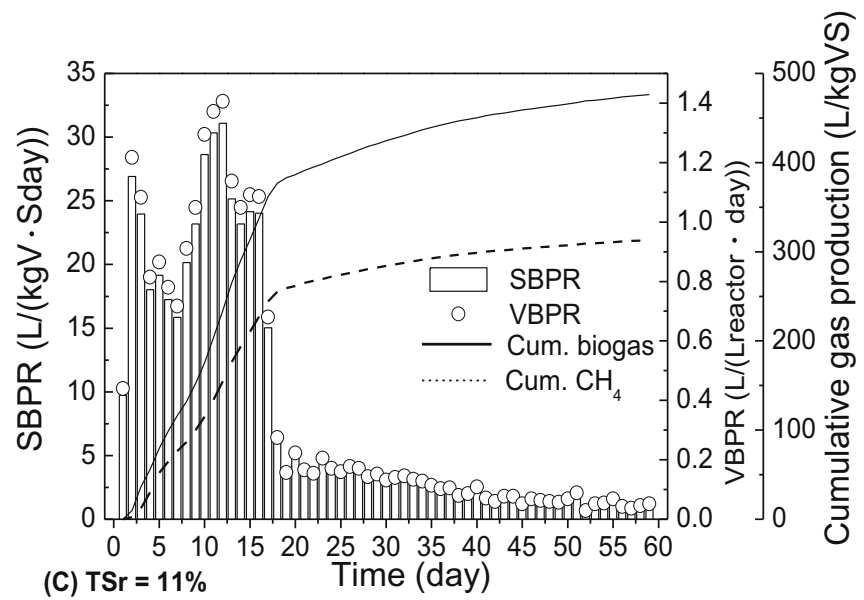

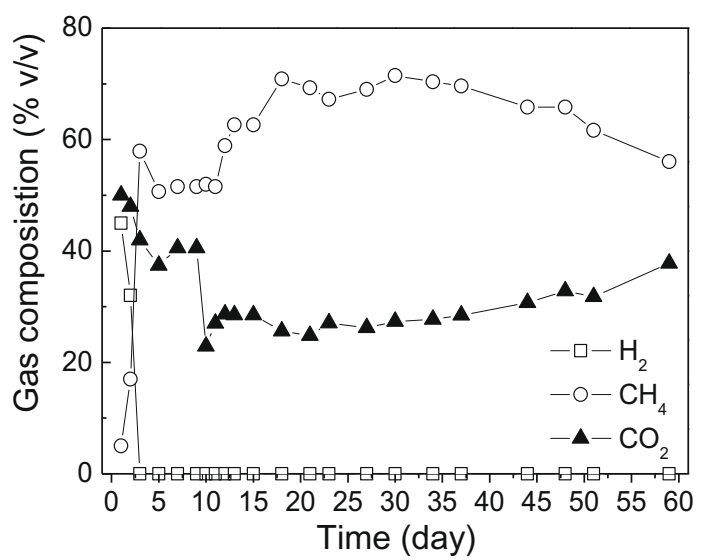
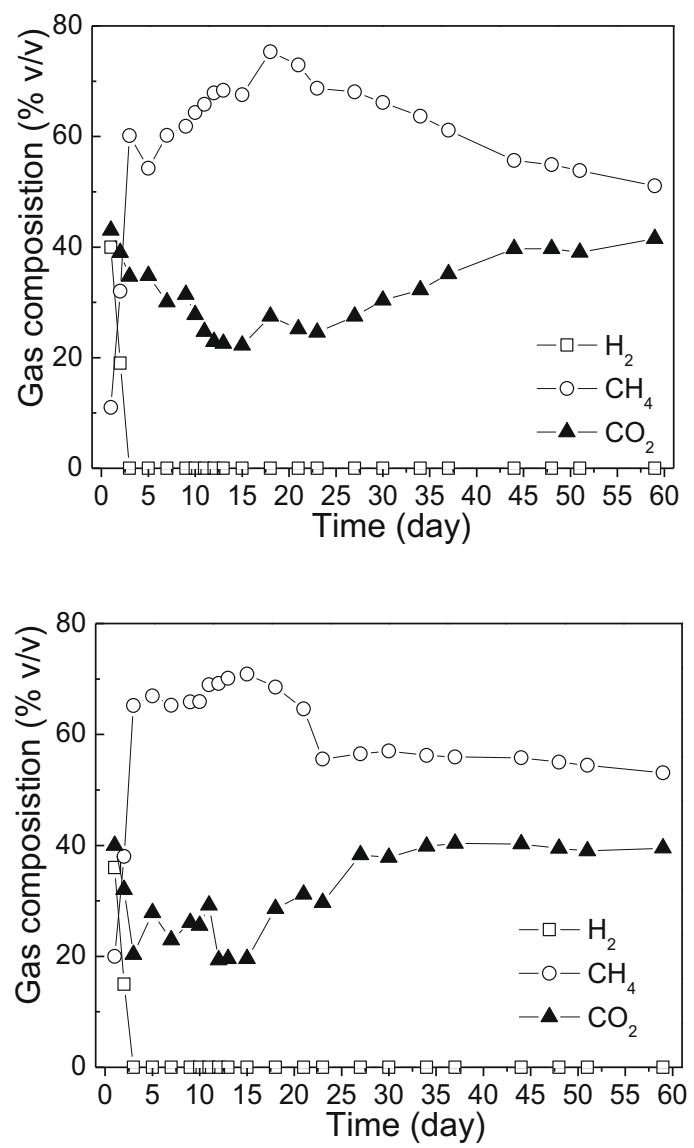

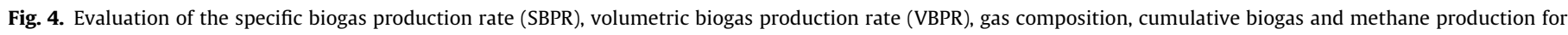
three TSr. 
more difficult than that of butyrate and valerate to acetate. This explained why the propionate concentration was higher than others during first and second stage in present study. During the final stage, the balance between the hydrolysis/acidogenesis and methanogenesis was formed. The produced volatile fatty acids were immediately consumed to generate methane. Sometimes, the volatile fatty acid concentrations were lower than the detection limits. It indicates that the hydrolysis of organic waste was ratelimiting step. This situation usually occurs in later period when the remaining substrate is the hard biodegradable fraction such as lignocellulose, feathers and leather.

The hydrolysis of amino acids and proteins generated the accumulation of ammonia during the early 10, 6 and 6 days for TSr $16 \%$, $13.5 \%$ and $11.0 \%$. Afterwards, the decreases of $\mathrm{NH}_{4}^{+}-\mathrm{N}$ concentration were observed since the $\mathrm{NH}_{4}^{+}-\mathrm{N}$ was used as nitrogen source for methanogens growth. After a relatively smooth period, the concentrations of $\mathrm{NH}_{4}^{+}-\mathrm{N}$ started to increase again at day 30. This could be because that the protein-containing hard biodegradable fraction (such as feathers and leather) began to hydrolyze after 30 days of soakage.

\subsection{Biogas production}

The specific biogas or methane production rate (SBPR or SMPR), volumetric biogas or methane production rate (VBPR or VMPR), methane content, cumulative biogas and methane production are used to describe the biogas production process and the results are illustrated in Fig. 4. The profile of SMPR and VMPR (data not displayed in this paper) were similar to that of SBPR and VBPR.

The lower TSr was favorable for increasing both SBPR and VBPR, for improving cumulative methane production, and for shortening digestion period. The maximum SBPR of $31 \mathrm{~L} /(\mathrm{kgVS}$.day) was observed at day 12 for TSr $11.0 \%$ and the maximum VBPR of $1.47 \mathrm{~L} /$ (L.day) was found at day 24 for TSr $13.5 \%$. The cumulative methane productions at the end of day 60 were 273,283 and $314 \mathrm{~L} / \mathrm{kgVS}$. Eighty percent of total biogas production was completed in the period of early 34, 29 and 19 days for TSr $16.0 \%, 13.5 \%$ and $11.0 \%$. Fig. 4 also indicates that there was no obvious inhibition of metals on anaerobic digestion.

Two distinct peaks of biogas and methane production rate were detected in all reactors. The first small peaks were observed at day 3, 2 and 2, and the second peaks were found at day 32, 25 and 12 for TSr $16 \%, 13.5 \%$ and $11.0 \%$, respectively. Charles et al. (2009) also observed two peaks of methane production rate in his batch thermophilic anaerobic digestion of organic municipal solid waste. He believed that the second peak corresponded with the acetate consumption; however, the first peak of methane production was related with $\mathrm{H}_{2} / \mathrm{CO}_{2}$ consumption. In this study, the first peak coincided with accumulation of acetate (Fig. 3) and with decreas- ing of $\mathrm{H}_{2} / \mathrm{CO}_{2}$ concentration (Fig. 4). This suggested that unlike continuously fed anaerobic digesters (operating at steady state), the batch anaerobic digestion of solids waste systems (such as WS-OFMSW) creates a dynamic change of the conditions. The hydrolysis and acidogenesis of easy biodegradable organic fraction generated both volatile fatty acids and $\mathrm{H}_{2}$ during start-up. Since the methanogenesis from acetate (aceticlastic methanogenesis) was limited in the presence of high $\mathrm{H}_{2}$ partial pressure (Ferguson and Mah, 1983; Lee and Zinder, 1988), it is most likely that methane formed purely from $\mathrm{H}_{2} / \mathrm{CO}_{2}$ (hydrogenotrophic methanogenesis) rather than from acetate at start-up stage (Eastman and Ferguson, 1981). Once the $\mathrm{H}_{2}$ partial pressure was reduced, its inhibitory effect on the aceticlastic methanogenesis diminished.

\subsection{Comparative process efficiency}

After 60 days of anaerobic digestion, the characteristics of digested residue of WS-OFMSW in all reactors were analyzed and the results are presented in Table 4 . The lower TSr obtained the higher organic matter removal. Compared with carbohydrates, crude fibers and proteins, the lipids achieved the maximum relative removal of $45.8 \%, 46.9 \%$ and $53.1 \%$ for TSr $16.0 \%, 13.5 \%$ and $11.0 \%$, respectively. The low relative removal of carbohydrates resulted from the presence of hard biodegradable lignocellulose such as chopsticks and branches. And the existence of hard biodegradable proteins such as feathers and leathers lowered the relative removal of proteins.

Table 5

Comparison of anaerobic digestion performance for different TSr.

\begin{tabular}{|c|c|c|c|c|}
\hline $\mathrm{TSr}$ & $16.0 \%$ & $13.5 \%$ & $11.0 \%$ & SS-OFMSW \\
\hline Feed (kgTS) & 3.44 & 3.33 & 2.80 & - \\
\hline Feed (kgVS) & 2.07 & 1.91 & 1.58 & - \\
\hline Residue (kgTS) & 2.97 & 2.46 & 2.02 & - \\
\hline Residue (kgVS) & 1.53 & 1.23 & 0.92 & - \\
\hline TS removal (\%) & 13.7 & 26.1 & 27.9 & - \\
\hline VS removal (\%) & 26.1 & 35.8 & 41.8 & $74-89$ \\
\hline $\operatorname{VBPR}\left(\mathrm{L} /\left(\mathrm{L}_{\text {reactor}} \cdot \mathrm{d}\right)\right)$ & 1.1 & 1.5 & 1.4 & - \\
\hline $\operatorname{SBPR}\left(\mathrm{L} /\left(\mathrm{kgVS}_{\text {feed }} \cdot \mathrm{d}\right)\right)$ & 19.0 & 27.4 & 31.1 & - \\
\hline Biogas yield $\left(\mathrm{L} / \mathrm{kgTS}_{\mathrm{feed}}\right)$ & 260 & 263 & 294 & - \\
\hline Biogas yield $\left(\mathrm{L} / \mathrm{kgVS}_{\text {feed }}\right)$ & 423 & 427 & 478 & - \\
\hline $\mathrm{CH}_{4}$ yield $\left(\mathrm{L} / \mathrm{kgTS}_{\text {feed }}\right)$ & 168 & 174 & 193 & - \\
\hline $\mathrm{CH}_{4}$ yield $\left(\mathrm{L} / \mathrm{kgVS}_{\text {feed }}\right)$ & 273 & 283 & 314 & $275-410$ \\
\hline Average $\mathrm{CH}_{4}(\%)$ & 65 & 66 & 66 & $58-64$ \\
\hline$E_{\mathrm{AD}}(\%)$ & 54 & 56 & 62 & $50-75$ \\
\hline
\end{tabular}

a Source sorted organic household waste from five Danish cities (Davidsson et al., 2007); VBPR: the maximum volumetric biogas production rate; SBPR: the maximum specific biogas production rate; average $\mathrm{CH}_{4}$ : cumulative methane production/cumulative biogas production; $E_{\mathrm{AD}}$ : efficiency of anaerobic digestion, $E_{\mathrm{AD}}=\mathrm{CH}_{4}$ yield/theoretical methane potential based on component composition.

Table 4

Characteristics of digested residue of WS-OFMSW

\begin{tabular}{|c|c|c|c|c|c|c|}
\hline $\mathrm{TSr}$ & $16.0 \%$ & & $13.5 \%$ & & $11.0 \%$ & \\
\hline Heat value (MJ/kgTS) & 12.7 & $(-39.5 \%)$ & 12.1 & $(-42.4 \%)$ & 11.3 & $(-46.2 \%)$ \\
\hline VS (\% of TS) & 51.5 & $(-16.4 \%)$ & 50.9 & $(-17.4 \%)$ & 44.3 & $(-28.1 \%)$ \\
\hline Carbohydrates (\% of TS) & 33.6 & $(-11.1 \%)$ & 32.9 & $(-13.0 \%)$ & 28.8 & $(-23.8 \%)$ \\
\hline Crude fibers (\% of TS) & 6.2 & $(-26.2 \%)$ & 6.0 & $(-28.6 \%)$ & 5.3 & $(-36.9 \%)$ \\
\hline Proteins (\% of TS) & 12.7 & $(-10.6 \%)$ & 12.4 & $(-12.7 \%)$ & 10.9 & $(-23.2 \%)$ \\
\hline Lipids (\% of TS) & 5.2 & $(-45.8 \%)$ & 5.1 & $(-46.9 \%)$ & 4.5 & $(-53.1 \%)$ \\
\hline Carbon (\% of TS) & 27.5 & $(-27.1 \%)$ & 26.9 & $(-28.6 \%)$ & 24.8 & $(-34.2 \%)$ \\
\hline Hydrogen (\% of TS) & 4.1 & $(-28.1 \%)$ & 4.0 & $(-29.8 \%)$ & 3.4 & $(-40.4 \%)$ \\
\hline Oxygen (\% of TS) & 17.5 & $(17.4 \%)$ & 17.7 & $(18.8 \%)$ & 14.6 & $(-2.0 \%)$ \\
\hline Nitrogen (\% of TS) & 1.8 & $(-45.5 \%)$ & 1.7 & $(-48.5 \%)$ & 1.5 & $(-54.5 \%)$ \\
\hline Sulfur (\% of TS) & 0.6 & $(530.0 \%)$ & 0.6 & $(500.0 \%)$ & 0.6 & (490.0\%) \\
\hline Phosphorus (\% of TS) & 0.4 & $(80.0 \%)$ & 0.3 & $(65.0 \%)$ & 0.3 & $(40.0 \%)$ \\
\hline
\end{tabular}

The data in brackets is relative variation rate calculated as: (value of digested residue - value of feed material)/value of feed material. 
Table 5 shows the overall anaerobic digestion performance for different TSr. The highest VS removal rate achieved $41.8 \%$ which was much lower than that of SS-OFMSW. The methane yield was approximately equivalent to the lower value of SS-OFMSW. And the efficiency of anaerobic digestion from WS-OFMSW was between the values from SS-OFMSW. However, the average methane contents were slightly higher than that of SS-OFMSW.

Generally speaking, water separation technology is a significant attempt and progress for municipal solid waste treatment in China. The organic fraction can be effectively separated from municipal solid waste and used as substrate for biogas production by anaerobic digestion. However, there is still a room for improving of separation effect. The first task is to reduce the inorganic component such as small gravel and sand which are contained in organic fraction. The second is to effectively separate the combustible but hard biodegradable organic matter such as chopstick, small piece of branches, wood and bamboo. On the other hand, pretreatment of WS-OFMSW for enhancing biodegradability and thermophilic anaerobic digestion for improving biogas production performance are suggested and being carried out in our group.

\section{Conclusion}

The volatile solid of WS-OFMSW is $61.6 \%$. There were no inhibitions of metal ions, volatile fatty acids and ammonia on anaerobic digestion at operation conditions of TSr 11.0-16.0\% and mesophilic $30{ }^{\circ} \mathrm{C}$. Compared with TSr $16.0 \%$ and $13.5 \%$, TSr $11.0 \%$ not only obtained higher methane yield and VS removal but also shortened the digestion period. A methane yield of $314 \mathrm{~L} / \mathrm{kgVS}$ and a VS removal of $41.8 \%$ were expected for 60 days mesophilic digestion with TSr $11.0 \%$. Around $80 \%$ of methane production was completed during the early 19 days. The average methane content in biogas was 66\%.

\section{Acknowledgements}

This research was financially supported by the Guangdong Science and Technology Program (No. 0711031100011). The authors wish to thank Guo Yangfeng of Guangzhou Institute of Energy Conversion (GIEC) for assistance in the installation of the experimental apparatus and chemical analysis. Finally, the raw material in this study was provided by WST International (Holding) Limited Company.

\section{Reference}

Adhikari, B.K., Barrington, S., Martinez, J., 2006. Predicted growth of world urban food waste and methane production. Waste Management Research 24 (5), 421433.

APHA, 1995. Standard Method for the Examination of Water and Wastewater. American Public Health Association, New York, USA.

Bolzonella, D., Pavan, P., Mace, S., Cecchi, F., 2006a. Dry anaerobic digestion of differently sorted organic municipal solid waste: a full-scale experience. Water Science and Technology 53 (8), 23-32.

Bolzonella, D., Battistoni, P., Susini, C., Cecchi, F., 2006b. Anaerobic codigestion of waste activated sludge and OFMSW: the experiences of Viareggio and Treviso plants (Italy). Water Science and Technology 53 (8), 203-211.

Bouallagui, H., Touhami, Y., BenCheikh, R., Hamdi, M., 2005. Bioreactor performance in anaerobic digestion of fruit and vegetable wastes. Process Biochemistry 40 (3-4), 989-995.

Buswell, E.G., Neave, S.L., 1930. Laboratory Studies of Sludge Digestion. Illinois Division of State Water Survey, Bulletin No. 30.
Charles, W., Walker, L., Cord-Ruwisch, R., 2009. Effect of pre-aeration and inoculum on the start-up of batch thermophilic anaerobic digestion of municipal solid waste. Bioresource Technology 100 (8), 2329-2335.

Chen, Y., Cheng, J.J., Creamer, K.S., 2008. Inhibition of anaerobic digestion process: a review. Bioresource Technology 99 (10), 4044-4064.

Davidsson, Å., Gruvberger, C., Christensen, T.H., Hansen, T.L., Jansen, J.L.C., 2007. Methane yield in the source-sorted organic fraction of municipal solid waste. Waste Management 27 (3), 406-414.

Eastman, J.A., Ferguson, J.F., 1981. Solubilization of particulate organic carbon during the acid phase of anaerobic digestion. Journal of the Water Pollution Control Federation 53 (3), 352-366.

Edgar-Fernando, C.M., Cristancho, D.E., Victor, A.A., 2006. Study of the operational conditions for anaerobic digestion of urban solid wastes. Waste Management 26 (5), 546-556.

Ferguson, T.J., Mah, R.A., 1983. Effect of $\mathrm{H}_{2}-\mathrm{CO}_{2}$ on methanogenesis from acetate or methanol in Methanosarcina spp. Applied and Environmental Microbiology 46 (2), 348-355.

Forster-Carneiro, T., Pérez, M., Romero, L.I., Sales, D., 2007. Dry-thermophilic anaerobic digestion of organic fraction of the municipal solid waste: focusing on the inoculum sources. Bioresource Technology 98 (17), 3195-3203.

Forster-Carneiro, T., Pérez, M., Romero, L.I., 2008. Anaerobic digestion of municipal solid wastes: dry thermophilic performance. Bioresource Technology 99 (17), 8180-8184.

Gallert, C., Henning, A., Winter, J., 2003. Scale-up of anaerobic of the biowaste fraction from domestic wastes. Water Research 37 (6), 433-1441.

Gómez, X., Cuetos, M.J., Cara, J., Morán, A., García, A.I., 2006. Anaerobic co-digestion of primary sludge and the fruit and vegetable fraction of the municipal solid wastes: conditions for mixing and evaluation of the organic loading rate. Renewable Energy 31 (12), 2017-2024.

Hanaki, K., Hirunmasuwan, S., Matsuo, T., 1994. Protection of methanogenic bacteria from low $\mathrm{pH}$ and toxic materials by immobilization using polyvinyl alcohol. Water Research 28 (4), 877-885.

Hartmann, H., Ahring, B.K., 2005. Anaerobic digestion of the organic fraction of municipal solid waste: influence of co-digestion with manure. Water Research 39 (8), 1543-1552.

Kim, M., Ahn, Y.H., Speece, R.E., 2002. Comparative process stability and efficiency of anaerobic digestion; mesophilic vs thermophilic. Water Research 36 (17), 4369-4385.

Krzystek, L., Ledakowicz, S., Kahle, H.J., Kaczorek, K., 2001. Degradation of household biowaste in reactors. Journal of Biotechnology 92 (2), 103-112.

Lee, M.J., Zinder, S.H., 1988. Hydrogen partial pressures in a thermophilic acetateoxidizing methanogenic coculture. Applied and Environmental Microbiology 54 (6), 1457-1461.

Li, D., Yuan, Z.H., Zhang, Y., Sun, Y.M., Kong, X.Y., Li, L.H., 2008. Anaerobic biochemical methane potential of organic fraction of municipal solid waste. Acta Scientiae Circumstantiae (in Chinese) 28 (11), 2284-2290.

Li, D., Sun, Y.M., Yuan, Z.H., Zhang, Y., Kong, X.Y., Li, L.H., 2009. Influences of feedstock proportion and $\mathrm{pH}$ value on anaerobic co-digestion of kitchen waste and waste paper. Chinese Journal of Process Engineering 9 (1), 53-58 (in Chinese).

Lopes, W.S., Leite, V.D., Prasad, S., 2004. Influence of inoculum on performance of anaerobic reactors for treating municipal solid waste. Bioresource Technology 94 (3), 261-266.

National Bureau of Statistics, PR China, 2007. China statistical yearbook 2005. China Statistical Press, Beijing, China (in Chinese).

Nguyen, P.H.L., Kuruparan, P., Visvanathan, C., 2007. Anaerobic digestion of municipal solid waste as a treatment prior to landfill. Bioresource Technology 98 (2), 380-387.

Rao, M.S., Singh, S.P., 2004. Bioenergy conversion studies of organic fraction of MSW: kinetic studies and gas yield-organic loading relationships for process optimization. Bioresource Technology 95 (2), 173-185.

Reith, J.H., Wijffels, R.H., Barten, H., 2003. Bio-methane and Bio-hydrogen: Status and Perspectives of Biological Methane and Hydrogen Production. Dutch Biological Hydrogen Foundation, Petten, Netherlands.

Silvey, P., Pullammanappallil, P.C., Blackall, L., Nichols, P., 2000. Microbial ecology of the leach bed anaerobic digestion of unsorted municipal solid waste. Water Science and Technology 41 (3), 9-16.

Stroot, P.G., Mcmahon, K.D., Mackie, R.I., Raskin, L., 2001. Anaerobic codigestion of municipal solid waste and biosolids under various mixing conditions - I Digester performance. Water Resources 35 (7), 1804-1816.

WST, 2009 WST. <http://www.wstinc.com/eng/abt_co.html>(accessed 11.08.2009).

Wu, M.C., Sun, K.W., 2006. Effect of temperature fluctuation on performance of thermophilic anaerobic digestion for treating organic fraction of municipal solid waste. Environmental Science (in Chinese) 27 (4), 805-809.

Xu, W.L., Lu, Y.F., Walder, R., Xu, H.Y., 2006. Municipal Solid Waste Management and Treatment Technology $[\mathrm{M}]$. China Architecture and Building Press, Beijing, China (in Chinese). 